\title{
Parity of the Dorper sheep does not influence the reproductive and productive response when they are synchronized with an "ultra-short" protocol
}

\begin{abstract}
The aim of the present study was to evaluate the reproductive and productive response of multiparous and primiparous Dorper sheep synchronized with an "ultra-short" protocol and a dose of $200 \mathrm{IU}$ of eCG. The $100 \%$ of the sheep responded to estrus during the experiment $(\mathrm{P}>0.05)$, being lower in the multiparous sheep than in the primiparous. However, the time to estrus was lower $(\mathrm{P}<0.05)$ in multiparous compared to primiparous. Fertility, type of delivery and length of gestation were not affected by the treatment $(\mathrm{P}>0.05)$. On the other hand, litter size at lambing, litter weight and survival rate at $30 \mathrm{~d}$ were similar in both groups of sheep $(\mathrm{P}>0.05)$. Is concluded that the ultra-short hormonal treatment is sufficient for $100 \%$ of the sheep, regardless of their parity, to respond to estrus. Also, the productive behaviour of the sheep was not affected by the treatment.
\end{abstract}

Keywords: biotechnologies, estro, hormones, primiparous sheep, weight, survival
Volume 2 Issue 3 - 2018

\author{
Ethel Caterina García y González,' Ulises \\ Macías Cruz, ${ }^{2}$ Leonel Avendaño Reyes, ${ }^{2}$ José \\ Vicente Velázquez Morales, ${ }^{3}$ Ricardo Vicente \\ Pérez, ${ }^{4}$ Santiago Zúñiga, ${ }^{5}$ José Luis Ponce' \\ 'Escuela Superior de Medicina Veterinaria y Zootecnia, No. 2, \\ Universidad Autónoma de Guerrero, Mexico \\ ${ }^{2}$ Instituto de Ciencias Agrícolas, Universidad Autónoma de Baja \\ California, Mexico \\ ${ }^{3}$ Programa de Ganadería, Colegio de Postgraduados, Mexico \\ ${ }^{4}$ Departamento de Producción Agrícola, Universidad de \\ Guadalajara, Mexico \\ ${ }^{5}$ Facultad de Agronomía y Zootecnia, Universidad Juárez del \\ Estado de Durango, Mexico
}

\begin{abstract}
Correspondence: José Luis Ponce, Escuela Superior de Medicina Veterinaria y Zootecnia No. 2, Universidad Autónoma de Guerrero, Carretera Acapulco-Pinotepa Nacional Km 197, 41940, Cuajinicuilapa, Guerrero, Mexico, Tel + 52 (55) 48-39-4I76,Email poncel285@hotmail.com
\end{abstract}

Received: May 29, 2018 | Published: June 06, 2018
Abbreviations: CIDR, intravaginal device containing progesterone; eCG, equine chorionic gonadotropin; PGF2 $\alpha$, prostaglandin $\mathrm{F} 2 \alpha$

\section{Introduction}

In sheep and goats, estrus synchronization protocols are a useful tool to improve reproductive efficiency. ${ }^{1,2}$ The classic protocols for synchronizing estrus in sheep consist in an intravaginal insertion of a sponge or an intravaginal device containing progesterone (CIDR) impregnated with flurogestone acetate or medroxyprogesterone (FGA or MAP) for 11 to $21 \mathrm{~d}$, accompanied by an intramuscular injection of equine chorionic gonadotropin $(\mathrm{eCG})$ at the end of the treatment. ${ }^{3-5}$ In goats to which a device with progestogen was inserted, an increase in serum progesterone concentrations was observed in the first 3 to $5 \mathrm{~d}(>5 \mathrm{ng} / \mathrm{ml})$, later these levels decreased $(2 \mathrm{ng} / \mathrm{ml})$ on day 6 to $12 .{ }^{6}$ In some studies decreased the duration of estrus synchronization protocols (5-7d); for the purpose to avoiding prolonged exposure to plasma progesterone. ${ }^{7-10}$ These protocols were accompanied by a dose of prostaglandin F2 $\alpha$ (PGF2 $\alpha$ ) at the start of the treatment and a low dose of eCG (200-300 IU) upon removal of the intravaginal device. In sheep synchronized with a short protocol of FGA and low doses of eCG is enough for $90 \%$ respond to estrus and these females have a high fertility. ${ }^{7-11}$ In Pelibuey sheep synchronized with low doses of eCG (100 and $200 \mathrm{IU}$ ) they found a high response to estrus (93 and $96 \%$ ) and gestation percentage (77 and $70 \%) .{ }^{12}$ On the other hand, Macías-Cruz et al. ${ }^{11}$ synchronized hair sheep with a progestogen and low doses of eCG (140 and $280 \mathrm{IU}$ ) and found a high response to estrus $(100 \%$ vs. $100 \%)$ and fertility (70\% vs. $74 \%)$. Therefore, the aim of the present study was evaluate the reproductive and productive response of multiparous and primiparous Dorper sheep synchronized with an "ultra-short" protocol and a dose of 200 IU of eCG.

\section{Materials and methods}

\section{General}

The experiment was conducted during the month of October 2017 in the ovine post "Ángeles" located in the municipality of Texcoco, state of Mexico, Mexico (coordinates: 19³0’20" north latitude and $98^{\circ} 52^{\prime} 55^{\prime \prime}$ west longitude). The region as a semi-dry temperate climate, with an average annual rainfall and temperature of $15.9{ }^{\circ} \mathrm{C}$ and $686 \mathrm{~mm}$, respectively. ${ }^{13}$ All procedures involving animals were conducted within the guidelines of approved local official techniques of animal care in México (NOM-051-ZOO-1995: Humanitarian Care of Animals During Mobilization).

\section{Animals and experimental design}

For the study, 14 Dorper sheep of 0 and 2 lambing were used, with a live weight of $34 \pm 2.4 \mathrm{~kg}$ and body condition scala (BCS) of $3.5 \pm 0.08$ points ( 1 to 5$),{ }^{14}$ subsequently the live weight and $\mathrm{BCS}$ were recorded every 15 (Figure 1) and 30 (Figure 2) d, respectively. From the total number of females, 2 groups of 7 sheep were formed, these were balanced according to their parity (primiparous and multiparous) and BCS. In the present study there was no control group to which hormonal treatment was not applied. However, it's known that in progestogen-based estrus synchronization protocols in sheep, the 
estrous response is similar when the devices remain inserted vaginally for $14 \mathrm{~d}^{11}$ than when they only last $5 \mathrm{~d} ; ;^{15}$ only that these protocols must be accompanied by a dose of eCG to increase ovulation, prolificacy and the time to estrus being short. The optimal dose of eCG required by wool sheep is $400 \mathrm{IU}^{16}$ and $300 \mathrm{IU}$ of hair. ${ }^{12}$ The sheep were treated with an "ultra-short" protocol described by Rubianes and Menchaca. ${ }^{17}$ The protocol consisted in the insertion of an intravaginal device with $0.3 \mathrm{~g}$ of progesterone contained in an intravaginal devices (CIDR ${ }^{\circledR}$, Intervet México S. de R.L. de C.V.), at the time of insertion of the CIDR, intramuscular injection of a dose of PGF2 $\alpha(160 \mu \mathrm{g}$ Lutalyse ${ }^{\circledR}$ ), when removing the device, 200 IU of eCG (Folligon, Intervet Mexico S.A. de C.V.) were applied, and $24 \mathrm{~h}$ after removing the device an intramuscular injection of $200 \mu \mathrm{g}$ of Estradiol Benzoate BE, Figure 3. The device remained in the females for $6 \mathrm{~d}$. Finally, $30 \mathrm{~h}$ after removing the device, the females were registered with a Dorper male, and it was ensured that each sheep received two mounts to corroborate that all were mounted.



Figure I The live weight of the multiparous ( $\square$ ) and primiparous ( $\square$ ) sheep, measured every $15 \mathrm{~d}$ during the entire gestation.

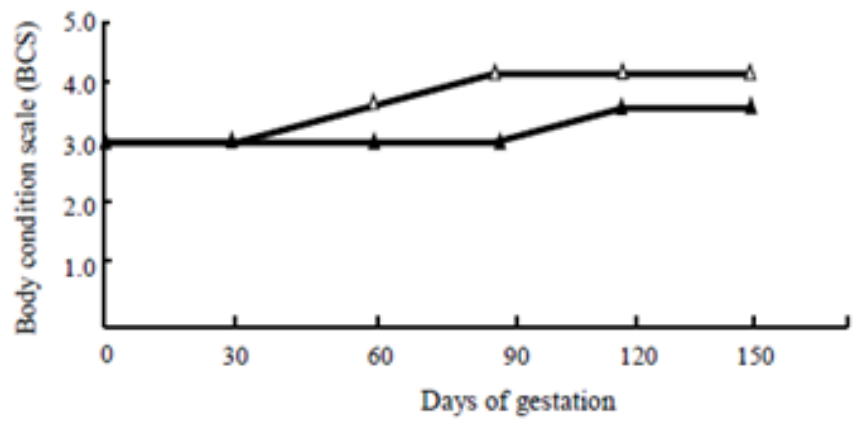

Figure 2 The body condition scale of the multiparous $(\Delta)$ and primiparous $(\boldsymbol{\Delta})$ sheep measured every $30 \mathrm{~d}$ during the entire gestation.

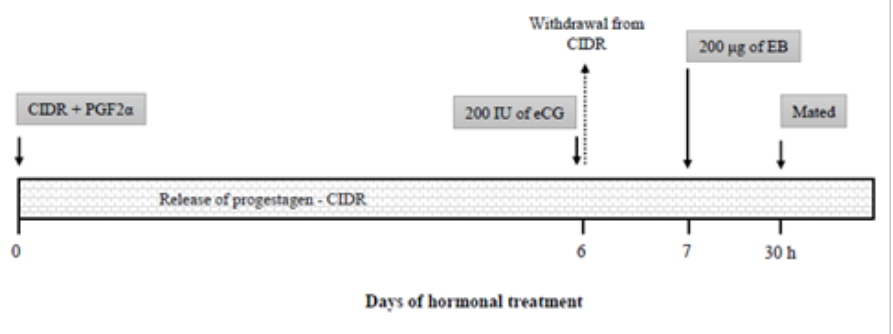

Figure 3 Outline of the experimental design evaluating the Ultra-Short Protocol (6 d of progesterone treatment plus PGF2 $\alpha$ at device insertion). On day $0 \mathrm{CIDR}+\mathrm{PGF} 2 \alpha$ was applied, on day 6 the CIDR was removed and intramuscular $200 \mathrm{IU}$ of eCG, on day 7 intramuscular $200 \mu \mathrm{g}$ of EB, $30 \mathrm{~h}$ later the sheep were mounted.

\section{Housing and feeding}

The sheep were housed in two open corrals circulated with cyclonic mesh and roofed with galvanized sheet, these pens were provided with drinking troughs and feeders. Ewes were placed into two pens based on parity, and feed at free access with a mixture of chopped forage ( $50 \%$ sudangrass hay and $50 \%$ alfalfa hay). Diet was served once a day (at $0800 \mathrm{~h}$ ), and the water was offered ad libitum. The chemical composition of the diet was $895 \mathrm{~g}$ of dry matter (DM)/ $\mathrm{kg}$ of mixture, $120 \mathrm{~g}$ of crude protein $(\mathrm{CP}) / \mathrm{kg}$ of DM, and $2.1 \mathrm{Mcal}$ of metabolizable energy (ME) $/ \mathrm{kg}$ of DM, which covers the nutritional requirements specified by the National Research Council ${ }^{18}$ for sheep at the time of breeding (ME $1.9 \mathrm{Mcal} / \mathrm{kg} \mathrm{DM}$ and CP $80 \mathrm{~g} / \mathrm{kg} \mathrm{DM}$ ) and gestation (ME 1.9-2.4 kg DM and CP 85-105 g/kg DM).

\section{Evaluated variables}

In all the females the variables of reproductive behaviour were evaluated: At parturition, lambing date and number of lambs born were recorded individually for each ewe. Response to estrus (percentage of ewes in estrus after sponge removal), time to estrus (interval of time between sponge removal and onset of estrus), fertility (percentage of ewes lambed from ewes mated), prolificacy (number of lambs born per ewe lambed), single (percentage of ewes lambed with one lamb) or multiple (percentage of ewes lambed with two or more lambs) lambing, and gestation length (interval of time between day of mating and lambing) were determined from collected information. Additionally, size of the litter per ewe lamb $(\mathrm{N})$ and survival rate per ewe lamb at 0,30 and $60 \mathrm{~d}$ (Table 2).

\section{Data analysis}

The data was analyzed with the statistical program SYSTAT ${ }^{19}$ under a randomized design. The variables of sexual behaviour were analyzed with the Chi-square test. On the other hand, the productive variables, mothers-offspring weights and body condition were subjected to one-way analysis of variance. The mean comparisons were made with the student $t$ test.

\section{Results and discussion}

\section{Sexual response of the sheep}

The $100 \%$ of the sheep responded to estrus during the experiment, regardless of parity. However, the time to estrus was affected by the treatment $(\mathrm{P}<0.05)$, being lower in the multiparous than in the primiparous sheep. On the other hand, the length of estrus was similar $(\mathrm{P}>0.05)$ between both groups of sheep $(22.6 \pm 0.2 \mathrm{vs} .22 .8 \pm 0.02 \mathrm{~h})$. Finally, fertility, single birth, multiple birth and length of gestation were not affected $(\mathrm{P}>0.05)$ by the treatment (Table 1$)$. The application of eCG to a protocol of synchronization of oestrus with progestagens improves the degree of induction and synchronization of endocrine and physiological events, which is reflected in an estrous behaviour where the interval to estrus post-withdrawal from CIDR is shorter. ${ }^{20}$ Indeed, in the present study the onset to estrus was shorter ( $36 \mathrm{~h})$ in multiparous sheep than previously reported in hair sheep (up to 48 h). ${ }^{1-12}$ Similar results were reported by Menchaca and Rubianes ${ }^{21}$ in goats subjected to an estrus synchronization protocol for $5 \mathrm{~d}$. These results indicate that the release of progesterone during the first days is sufficient in small ruminants to stimulate the first follicular wave and the estrous response. The same pattern in the elevation of the profiles of said hormone was observed in heifers synchronized with a progestogen. ${ }^{22}$ On the other hand, the response to sheep estrus in the present study was similar to that reported by Macías-Cruz et al. ${ }^{1}$ in hair sheep (100\% estrus) synchronized with a synthetic progestogen; 
but different (92\% estrus) from those recorded by Quintero-Elisea et al. ${ }^{12}$ The high estrous response reported by these authors is likely due to appropriate follicle stimulation and sufficient estradiol release for the females to show signs of estrus in a shorter time.

Table I Effect of low doses of eCG on the reproductive efficiency of multiparous and primiparous hair sheep

\begin{tabular}{lll}
\hline & Primiparous & Multiparous \\
\hline Treated sheep, N & 7 & 7 \\
Lambing sheep, $\mathrm{n}$ & $5 / 7$ & $7 / 7$ \\
Response to estrus, \% & $100 \mathrm{a}(7 / 7)$ & $100 \mathrm{a}(7 / 7)$ \\
Time to estrus, h & $41.6 \pm 0.9 \mathrm{a}$ & $36.6 \pm 0.8 \mathrm{~b}$ \\
Fertility, \% & $71(5 / 7) \mathrm{a}$ & $100(7 / 7) \mathrm{a}$ \\
Single lambing, \% & $80(4 / 5) \mathrm{a}$ & $71(5 / 7) \mathrm{a}$ \\
Multiple lambing, \% & $20(1 / 5) \mathrm{a}$ & $28(2 / 7) \mathrm{a}$ \\
Gestation length, (d) & $150.25 \pm 1.13 \mathrm{a}$ & $148.00 \pm 1.13 \mathrm{a}$ \\
\hline
\end{tabular}

${ }^{a, b} \mathrm{P}<0.05$ Different literal within row means significant difference.

\section{Productive behaviour}

The litter size at birth between multiparous sheep $(2.0 \pm 0.06$ offspring) and primiparous was similar ( $1.8 \pm 0.53$ offspring; $\mathrm{P}>0.05)$. In the same way, the weight of the litter was similar among sheep regardless of their parity $(4.75 \pm 0.43$ vs. $4.35 \pm 0.43 \mathrm{~kg})$. The survival rate of lambs at $30 \mathrm{~d}$ postpartum was also similar between both groups of sheep ( $92 \pm 0.1$ vs. $79 \pm 0.1$ d). On the other hand, the weight and body condition of all the sheep at the beginning of the experiment did not vary $(34 \pm 2.4 \mathrm{~kg}$ and $3.5 \pm 0.08$ points; $\mathrm{P}>0.05)$. On the other hand, at the weaning of the offspring $(60 \mathrm{~d})$ both weight and body condition were lower $(\mathrm{P}<0.05)$ in the primiparous than in the multiparous sheep ( $34.8 \pm 2.4$ vs. $40.61 \pm 3.52 \mathrm{~kg}$ and 3.5 vs. $4.0 \pm 0.08$ points) (Table 2 ). In the present study the size of the litter was not affected by the parity of the females. According to these results Sánchez-Dávila et al., ${ }^{23}$ found that litter size at lambing in Saint Croix primiparous sheep was similar (1.78 \pm 0.06 offspring) to that found in the present study. Contrary to these results Macías-Cruz et al., ${ }^{24}$ found litter size at lambing in higher Dorper sheep ( $2.0 \pm 0.06$ offspring) to those of the present study and those of the work done with Saint Croix sheep.

Table 2 Effect of low doses of eCG on the productive behaviour in multiparous and primiparous hair sheep

\begin{tabular}{lcc}
\hline & Primiparous & \multicolumn{1}{c}{ Multiparous } \\
\hline \multicolumn{3}{l}{ Size of the litter per ewe lamb $(\mathbf{N})$} \\
$0 \mathrm{~d}$ & $1.8 \pm 0.53$ & $2.0 \pm 0.06$ \\
$30 \mathrm{~d}$ & $1.47 \pm 0.38$ & $1.58 \pm 0.53$ \\
$60 \mathrm{~d}$ & $1.28 \pm 0.34$ & $1.42 \pm 0.56$ \\
Survival rate per ewe lamb & \\
$0 \mathrm{~d}$ & - & - \\
$30 \mathrm{~d}$ & $92 \pm 0.1$ & $79 \pm 0.1$ \\
$60 \mathrm{~d}$ & $89 \pm 0.2$ & $76 \pm 0.1$ \\
\hline
\end{tabular}

The results of the table do not show significant difference.

The results of survival rate per ewe lamb are presented as a percentage \pm SEM.
Regarding the weight of the litter at birth, it didn't change in the present study. In this sense Sánchez-Dávila et al., ${ }^{23}$ mention in their study that the parity of the sheep affected the weight of the litter, being lower in primiparous ewes $(3.01 \pm 0.1 \mathrm{~kg})$ than those that were from the second to the fifth lambing $(3.16 \pm 0.15 \mathrm{~kg})$. On the other hand, Macías-Cruz et al., ${ }^{1}$ found a weight of the litter in Dorper lambs inferior ( $3.57 \pm 0.12$ offspring) to the one found in the present study; they also observed that the weight of the litter decreased while the number of offspring increased per ewe lamb. The survival rate was not affected by the parity of the female. Consistently with this result Macías-Cruz et al., ${ }^{1}$ found a lower weaning survival rate $(82 \pm 0.03$ offspring) than that found in the present study ( $89 \pm 0.2$ offspring). It's known that the high percentage of mortality $(15 \%)$ in lambs is due to some factors such as: dead births, diarrhea, malnutrition and pneumonia mainly; ${ }^{25}$ but this percentage increases $(23 \%)$ when the mother raises more than 2 lambs. ${ }^{1-25}$ Productivity is related to birth weight, growth, maternal ability and mother's milk production. Low weights at birth influence the reduction of the litter survival rate in the first days of life, which directly impacts on a reduction in litter size and weight during the pre-weaning period. ${ }^{26}$ Additionally, if the sheep have low maternal skill and their level of milk production is also low or insufficient to maintain the entire litter, the growth of the offspring is negatively affected, often producing the death of the offspring. ${ }^{27}$ These results are probably due to the fact that both groups of sheep conserved the weight and body condition from the breeding until delivery.

\section{Conclusion}

The synchronization of estrus in multiparous and primiparous sheep with a protocol "ultra-short" based on a progestogen and a dose of $200 \mathrm{IU}$ of eCG is enough for $100 \%$ of females to respond to estrus and this is more short in multiparous than in primiparous sheep. Also, the productive behaviour of the sheep was not affected by the parity of the females and the application of a dose of eCG lower than that recommended in hair sheep.

\section{Acknowledgements}

None.

\section{Conflict of interest}

The author declares that there is no conflict of interest.

\section{References}

1. Macías Cruz U, Álvarez Valenzuela FD, Correa Calderón A, et al. Pelibuey ewe productivity and subsequent pre-weaning lamb performance using hair-sheep breeds under a confinement system. Journal of Applied Animal Research. 2009;36(2):255-260.

2. Leboeuf B, Forgerit Y, Bernelas D, et al. Efficacy of two types of vaginal sponges to control onset of oestrus, time of preovulatory LH peak and kidding rate in goats inseminated with variable numbers of spermatozoa. Theriogenology. 2003;60(7):1371-1378.

3. Corteel JM, Leboeuf B, Baril G. Artificial breeding of goats and kids induced to ovulate with hormones outside the breeding season. Small Ruminant Research. 1988;1(1):19-35.

4. Ponce JL, Macías U, Álvarez FD. Low doses of gonadotropin chorionic equine (GCe) to Pelibuey and Pelibuey x Romanov ewes. Cuban Journal Agricultural Science. 2013;47(1):33-36.

5. Martinez MF, McLeod B, Tattersfield G, et al. Successful induction of 
oestrus, ovulation and pregnancy in adult ewes and ewe lambs out of the breeding season using a $\mathrm{GnRH}+$ progesterone oestrus synchronisation protocol. Anim Reprod Sci. 2015;155:28-35.

6. Rubianes E, de Castro T, Kmaid S. Estrous response after a short progesterone priming in seasonally anestrous goats. Theriogenology. 1998;49:351-356.

7. Ungerfeld R, Rubianes E. Effectiveness of short progestagen priming for the induction of fertile oestrus with eCG in ewes during late seasonal anoestrus. Animal Science. 1999;68(3):349-353.

8. Rubianes E, Menchaca A, Ungerfeld R. Avances en las técnicas de sincronización de celos en ovinos y caprinos (Advances on oestrus synchronisation techniques in sheep and goats). In: Proceedings of the IV International Symposium on Animal Reproduction. Córdoba, Argentina, 2001;61-81.

9. Menchaca A, Rubianes E. New treatments associated with timed artificial insemination in small ruminants. Reproduction Fertility and Development. 2004;16(4):403-414.

10. García Pintos C, Menchaca A. Luteal response and follicular dynamics induced with equine chorionic gonadotropin (eCG) administration after insemination in sheep. Small Ruminant Research. 2016;136:202-207.

11. Macías Cruz U, Ponce Covarrubias JL, Álvarez Valenzuela FD, et al Reproductive efficiency of Pelibuey and Romanov x Pelibuey ewes synchronized with synthetic progestagen and low doses of PMSG under a hot environment. Czech Journal of Animal Science. 2013;58(12):546553.

12. Quintero Elisea JA, Macías Cruz U, Álvarez Valenzuela FD, et al. The effects of time and dose of pregnant mare serum gonadotropin (PMSG) on reproductive efficiency in hair sheep ewes. Trop Anim Health Prod. 2011;43(8):1567-1573.

13. García E. Modifications to the climatic classification system of Koppen to suit to the Mexican Republic conditions. 2nd edition. Instituto de Geografía, Universidad Nacional Autónoma de México. 1985.

14. Russell AJF, Doney JM, Gunn RJ. Subjective assessment of body fat in live sheep. Journal of Agricultural Science. 1969;72(3):451-454

15. Rubianes E, Menchaca A, Carbajal B. Response of the 1 to 5-day aged ovine corpus luteum to Prostaglandin F2 $\alpha$. Animal Reproduction Science. 2003;78(1-2):47-55.

16. Barrett DMW, Bartlewski PM, Batista Arteaga M, et al. Ultrasound and endocrine evaluation of the ovarian response to a single dose of 500 $\mathrm{IU}$ of eCG following a 12-day treatment with progestogen-releasing intravaginal sponges in the breeding and nonbreeding seasons in ewes. Theriogenology. 2004;61(2-3):311-327.
17. Rubianes E, Menchaca A. The pattern and manipulation of ovarian follicular growth in goats. Anim Reprod Sci. 2003;78(3-4):271-287.

18. National Research Council. Nutrient Requirements of Small Ruminants: Sheep, Goats, Cervids and New World Camelids. 1st edition. National Academies Press, Washington, USA. 2007.

19. SYSTAT 13. Product of Cranes Software International Ltd. San José, CA, USA. 2009.

20. Godfrey RW, Gray ML, Collins JR. The effect of ram exposure on uterine Involution and luteal function during the postpartum period of hair sheep ewes in the tropics. Journal of Animal Science. 1998;76(12):3090-3094.

21. Menchaca A, Rubianes E. Effect of high progesterone concentrations during the early luteal phase on the length of the ovulatory cycle of goats. Anim Reprod Sci. 2001;68(1-2):69-76.

22. Burke CR, Mihm M, Macmillan KL, et al. Some effects of prematurely elevated concentrations of progesterone on luteal and follicular characteristics during the oestrous cycle in heifers. Animal Reproduction Science. 1994;35(1-2):27-39.

23. Sánchez Dávila F, Bernal Barragán H, Padilla Rivas G, et al. Environmental factors and ram influence litter size, birth, and weaning weight in Saint Croix hair sheep under semi-arid conditions in Mexico. Tropical Animal Health Production. 2015;47(5):825-31.

24. Macías Cruz U, Álvarez Valenzuela FD, Olguín Arredondo HA, et al. Ovejas Pelibuey sincronizadas con progestágenos y apareadas con machos de razas Dorper y Katahdin bajo condiciones estabuladas: producción de la oveja y crecimiento de los corderos durante el período predestete. Archivos de Medicina Veterinaria. 2012;44(1):29-37.

25. Galina MA, Morales R, Silva E, et al. Reproductive performance of Pelibuey and Blackbelly sheep under tropical management systems in México. Small Ruminant Research. 1996;22(1):31-37.

26. Gardner DS, Buttery PJ, Daniel Z, et al. Factors affecting birth weight in sheep: maternal environment. Reproduction. 2007;133(1):297-307.

27. González GR, Torres G, Castillo M. Growth of blackbelly lambs between birth and final weight in the humid tropics of Mexico. Veterinaria México. 2002;33(4):443-453. 